\title{
STRATEGI KONTEKSTUAL UNTUK MENINGKATKAN KONEKSI DAN HASIL BELAJAR MATEMATIKA SISWA MTS
}

\author{
Sofana Imawati(1) \\ MTs Negeri 1 Pemalang \\ Soffana72@gmail.com
}

DOI: 10.23917/varidika.v32i2.13136

Submission
Track:
Received:
15 October 2020
Final Revision:
15 November 2020
Available online:
16 December 2020
Corresponding Author:
Sofana Imawati
Soffana72@gmail.com

Submission

Track:

\section{ABSTRAK}

Tujuan penelitian mendeskripsikan peningkatan koneksi dan hasil belajar matematika melalui penerapan strategi pembelajaran kontekstual. Penelitian menggunakan Penelitian Tindakan Kelas. Sumber data, guru dan siswa kelas 8.3 semester genap MTs Negeri 1 Pemalang 2019/2020. Metode pengumpulan data, observasi, catatan lapangan, dokumentasi, dan tes. Data dianalisis secara komparatif konstanta dan interaktif. Validitas data, triangulasi sumber dan metode. Hasil penelitian, penerapan strategi pembelajaran kontekstual dapat meningkatkan koneksi dan hasil belajar matematika. (1) Peningkatan koneksi matematika, (a) kemampuan menyampaikan materi dengan baik kepada teman satu kelompok dalam diskusimeningkat 40,54\%, (b) kemampuan mengarahkan dan mau berbagi caradengan menjelaskan tahapantahapan dalam penyelesaian soal dengan teman sebaya baik dalam kerja kelompok ataupun tidakmeningkat45,94\%, (c) keberanian maju ke depan kelas untuk menyampaikan dan menjelaskan pendapat ataupun mengerjakan soal tanpa harus ditunjuk oleh gurumeningkat 27,03\%, (d) kemampuan berkomunikasi secara efektif dengan orang lain dalam mencari tahu solusi dalam penyelesaian masalah (soal) meningkat 43,25\%, dan (e) kemampuan menyelesaiakan soal dengan konsep yang benar dan matangmeningkat 43,24\%. (2) Peningkatan hasil belajar matematika meningkat 45,95\%.

Kata kunci: hasil belajar, koneksi, kontekstual, matematika 


\section{PENDAHULUAN}

Koneksi dan hasil belajar matematika itu penting. Koneksi matematika merupakan keterkaitan antar konsep atau ide matematika yang akan memfasilitasi kemampuan siswa untuk memformulasi dan memverifikasi konjektur secara induktif dan deduktif, selanjutnya konsep, ide, dan prosedur matematika yang baru dikembangkan dapat diterapkan untuk menyelesaikan masalah lain dalam matematika atau disiplin ilmu lainnya (Permana dan Utari Sumarmo, 2007: 117).

Koneksi matematika berdampak pada hasil belajar matematika. Hasil belajar matematika penting. Hal ini karena perkembangan ilmu pengetahuan dan teknologi yang membutuhkan matematika. Perkembangan ilmu pengetahuan dan teknologi tersebut dapat digunakan untuk memperoleh informasi melalui berbagai sumber.

Hasil observasi awal kemampuan koneksi matematika siswa kelas 8.3 Mts tempat penelitian yang terdiri dari 37 siswa (laki-laki berjumlah 14 siswa dan perempuan berjumlah 23 siswa) belum sesuai harapan. Siswa yang mampu menyampaikan materi dengan baik kepada teman satu kelompok dalam diskusi sebanyak 4 siswa $(10,81 \%)$. Siswa yang mampu mengarahkan dan mau berbagi cara dengan menjelaskan tahapan-tahapan dalam penyelesaian soal dengan teman sebaya baik dalam kerja kelompok ataupun tidak sebanyak 3 siswa $(8,11 \%)$. Siswa yang berani maju ke depan kelas untuk menyampaikan dan menjelaskan pendapat ataupun mengerjakan soal tanpa harus ditunjuk oleh guru sebanyak 4 siswa (10,81\%). Siswa yang mampu berkomunikasi secara efektif dengan orang lain dalam mencari tahu solusi dalam penyelesaian masalah (soal) sebanyak 5 siswa (13,51\%). Siswa yang mampu menyelesaiakan soal dengan konsep yang benar dan matang sebanyak 3 orang $(8,11 \%)$.

Hasil analisis dokumen menunjukkan bahwa kondisi awal dari hasil belajar matematika kelas 8.3 Mts tempat penelitian juga belum sesuai harapan. Kondisi ini terlihat dari jumlah siswa yang tuntas dengan nilai lebih dari sama dengan 65 sebanyak 12 siswa $(32,43 \%)$.

Permasalahan koneksi dan hasil belajar matematika di atas akar penyebabnya bisa bersumber dari banyak faktor. Akar penyebabnya dapat bersumber dari guru, siswa, peralatan belajar, dan lingkungan belajar.

Berdasarkan beberapa faktor tersebut, faktor dominan berasal dari guru terutama dalam strategi pembelajaran. Pemilihan dan penggunaan strategi pembelajaran harus dibuat sesuai materi sehingga siswa dapat menerima pembelajaran dengan mudah. Proses pembelajaran akan menarik jika guru dapat menciptakan strategi pembelajaran yang tepat.

Salah satu alternatif yang digunakan adalahstrategi pembelajaran kontekstual atau Contextual Teaching And Learning (CTL). Strategi pembelajaran kontekstual merupakan sebuah proses pendidikan yang bertujuan menolong para siswa melihat makna di dalam materi akademik yang mereka pelajari dengan cara menghubungkan subjek-subjek akademik dengan 
konteks dalam kehidupan keseharian mereka, yaitu dengan konteks keadaan pribadi, sosial, dan budaya mereka (Johnson, 2011: 67).

Penelitian ini secara umum bertujuan untuk mendeskripsikan peningkatan koneksi dan hasil belajar siswa dalam pembelajaran matematika. Secara khusus terdapat dua tujuan dalam penelitian ini. (1) Mendeskripsikan peningkatan koneksi matematika bagi siswa kelas 8.3 semester genap MTs Negeri 1 Pemalang 2019/2020 melalui penerapan strategi pembelajaran kontekstual. (2) Mendeskripsikan peningkatan hasil belajar matematika bagi siswa kelas 8.3 semester genap MTs Negeri 1 Pemalang 2019/2020 melalui penerapan strategi pembelajaran kontekstual.

\section{METODE PENELITIAN}

Koneksi dan hasil belajar matematika itu penting. Koneksi matematika merupakan keterkaitan antar konsep atau ide matematika yang akan memfasilitasi kemampuan siswa untuk memformulasi dan memverifikasi konjektur secara induktif dan deduktif, selanjutnya konsep, ide, dan prosedur matematika yang baru dikembangkan dapat diterapkan untuk menyelesaikan masalah lain dalam matematika atau disiplin ilmu lainnya (Permana dan Utari Sumarmo, 2007: 117).

Koneksi matematika berdampak pada hasil belajar matematika. Hasil belajar matematika penting. Hal ini karena perkembangan ilmu pengetahuan dan teknologi yang membutuhkan matematika. Perkembangan ilmu pengetahuan dan teknologi tersebut dapat digunakan untuk memperoleh informasi melalui berbagai sumber.

Hasil observasi awal kemampuan koneksi matematika siswa kelas 8.3 Mts tempat penelitian yang terdiri dari 37 siswa (laki-laki berjumlah 14 siswa dan perempuan berjumlah 23 siswa) belum sesuai harapan. Siswa yang mampu menyampaikan materi dengan baik kepada teman satu kelompok dalam diskusi sebanyak 4 siswa $(10,81 \%)$. Siswa yang mampu mengarahkan dan mau berbagi cara dengan menjelaskan tahapan-tahapan dalam penyelesaian soal dengan teman sebaya baik dalam kerja kelompok ataupun tidak sebanyak 3 siswa $(8,11 \%)$. Siswa yang berani maju ke depan kelas untuk menyampaikan dan menjelaskan pendapat ataupun mengerjakan soal tanpa harus ditunjuk oleh guru sebanyak 4 siswa (10,81\%). Siswa yang mampu berkomunikasi secara efektif dengan orang lain dalam mencari tahu solusi dalam penyelesaian masalah (soal) sebanyak 5 siswa (13,51\%). Siswa yang mampu menyelesaiakan soal dengan konsep yang benar dan matang sebanyak 3 orang $(8,11 \%)$.

Hasil analisis dokumen menunjukkan bahwa kondisi awal dari hasil belajar matematika kelas 8.3 Mts tempat penelitian juga belum sesuai harapan. Kondisi ini terlihat dari jumlah siswa yang tuntas dengan nilai lebih dari sama dengan 65 sebanyak 12 siswa $(32,43 \%)$.

Permasalahan koneksi dan hasil belajar matematika di atas akar penyebabnya bisa bersumber dari banyak faktor. Akar penyebabnya dapat bersumber dari guru, siswa, peralatan belajar, dan lingkungan belajar. 
Berdasarkan beberapa faktor tersebut, faktor dominan berasal dari guru terutama dalam strategi pembelajaran. Pemilihan dan penggunaan strategi pembelajaran harus dibuat sesuai materi sehingga siswa dapat menerima pembelajaran dengan mudah. Proses pembelajaran akan menarik jika guru dapat menciptakan strategi pembelajaran yang tepat.

Salah satu alternatif yang digunakan adalahstrategi pembelajaran kontekstual atau Contextual Teaching And Learning (CTL). Strategi pembelajaran kontekstual merupakan sebuah proses pendidikan yang bertujuan menolong para siswa melihat makna di dalam materi akademik yang mereka pelajari dengan cara menghubungkan subjek-subjek akademik dengan konteks dalam kehidupan keseharian mereka, yaitu dengan konteks keadaan pribadi, sosial, dan budaya mereka (Johnson, 2011: 67).

Penelitian ini secara umum bertujuan untuk mendeskripsikan peningkatan koneksi dan hasil belajar siswa dalam pembelajaran matematika. Secara khusus terdapat dua tujuan dalam penelitian ini. (1) Mendeskripsikan peningkatan koneksi matematika bagi siswa kelas 8.3 semester genap MTs Negeri 1 Pemalang 2019/2020 melalui penerapan strategi pembelajaran kontekstual. (2) Mendeskripsikan peningkatan hasil belajar matematika bagi siswa kelas 8.3 semester genap MTs Negeri 1 Pemalang 2019/2020 melalui penerapan strategi pembelajaran kontekstual.

\section{HASIL PENELITIAN DAN PEMBAHASAN}

Kondisi awal pada siswa kelas 8.3 semester genap 2019/2020 MTs Negeri 1 Pemalang terlihat bahwa guru kurang optimal dalam memanfaatkan strategi pembelajaran inovatif. Guru masih menggunakan strategi yang konvensional dalam proses pembelajaran. Metode pembelajaran yang digunakan kurang bervariasi dan pembelajaran berpusat pada guru.

Pembelajaran yang dilaksanakantersebut berdampak pada rendahnya koneksi dan hasil belajar matematika.Berdasarkan hal itu, guru menerapkan strategi pembelajaran kontekstual untuk meningkatkan koneksi dan hasil belajar siswa. Pada tindakan siklus I, siswa dibagi menjadi beberapa kelompok yang beranggotakan 4-5 orang. Pembagian anggota kelompok tidak diatur oleh guru sehingga siswa dapat memilih anggota kelompoknya sendiri secara bebas.Pada tindakan siklus II, strategi pembelajaran yang digunakan sama dengan siklus sebelumnya yaitu strategi kontekstual. Namun, pembagian kelompok dalam siklus ini diatur oleh guru. Siswa membentuk kelompok dengan anggota kelompok yang sudah ditentukan oleh guru. Penerapan strategi pembelajaran kontekstual dapat meningkatkan koneksi dan hasil belajar matematika.

Berdasarkan uraian di atas maka guru harus dapat memilih dan menggunakan strategi pembelajaran yang inovatif. Khandaghi dan Maryam Farasat (2011)mengatakan, penggunaan strategi pembelajaran merupakan hal yang penting yang harus diperhatikan oleh guru agar hasil belajar dapat maksimal. 
Hasil penelitian yang dilakukan oleh Vikis (2008) juga mendukung perlunya penerapan strategi yang tepat dalam pembelajaran. Hasil penelitian tersebut menunjukkan bahwa guru harus memiliki rencana instruksional dan memberi fasilitas serta dukungan kepada siswa agar proses pembelajaran berlangsung dengan lancar. Pendapat lain yang menguatkan hasil pnelitian ini, yaitu Puteh dan Mahani Ibrahim (2010) mengatakan, guru harus dapat meningkatkan kesadaran siswa akan pentingnya strategi pembelajaran sehingga siswa dapat mengikuti proses pembelajaran dengan baik.

Dalam pembelajaran matematika guru memanfaatkan strategi kontekstual. Menurut Johnson (2011: 57) keunggulan strategi pembelajaran kontekstual meliputi 1) strategi pembelajaran kontekstual memberi kesempatan siswa untuk menemukan makna dan arti diri dalam pelajaran akademik dengan benar-benar mengaitkan pekerjaan sekolah dengan kehidupan sehari-hari dan minat siswa, 2) strategi pembelajaran kontekstual dapat digunakan oleh semua siswa baik yang sangat berbakat maupun siswa yang mengalami kesulitan belajar, 3) strategi pembelajaran kontekstual merupakan strategi yang sangat menarik di antara banyak metode pengajaran lainnya, 4) strategi pembelajaran kontekstual memberikan kesempatan kepada semua siswa untuk mengembangkan harapan mereka, untuk mengembangkan bakat mereka, dan mengetahui informasi terbaru, serta menjadi anggota sebuah masyarakat demokrasi yang cakap.

Hasil penelitian yang dilakukan oleh Deen (2006) mendukung penggunaan strategi pembelajaran kontekstual dalam pembelajaran. Hasil penelitian menunjukkan bahwa strategi pembelajaran kontekstual merupakan konsep yang relatif baru dalam pendidikan. Namun, strategi ini harus dianut oleh guru profesional karena penerapan strategi ini berlangsung secara teratur sehingga proses pembelajaran menjadi unik dan menarik.

Beberapa pendapat lain yang menguatkan penelitian ini, yaitu Komalasari (2012) mengatakan, strategi pembelajaran kontekstual memiliki pengaruh yang signifikan terhadap kemampuan siswa. Selain itu strategi ini juga dapat mengembangkan pemikiran siswa dan keterampilan partisipatif. Penelitian Perin (2011) yang menunjukkan bahwa strategi kontekstual merupakan keterkaitan konsep-konsep matematika yang dapat mengembangkan kemampuan dan motivasi belajar siswa.

Penelitian Suryawati, Kamisah Osman \& T. Subahan Mohd Meerah (2010) menujukkan bahwa strategi kontekstual RANGKA (Rumuskan, Amati, Nyatakan, Gabungkan, Komunikasi, Amalkan) membutuhkan kerjasama diantara guru dan siswa dimana guru berperan besar dalam memotivasi siswa. RANGKA kontekstual dapat meningkatkan kemampuan berfikir kritis siswa dan dapat melatih siswa untuk lebih evaliatif.

Coker, Hakan Catlioglu \& Osman Birgin (2010) mengatakan, dalam strategi pembelajaran kontekstual siswa memiliki kesempatan untuk menggabungkan konteks kehidupan sehari-hari dengan konteks materi. Oleh karean itu, siswa yang belajar dengan strategi pembelajaran kontekstual dapat memahami konsep-konsep materi dengan baik. Penelitian Debreli (2012) menunjukkan bahwa penerapan strategi pembelajaran kontekstual 
dilakukan dengan mengembangkan kesadaran penerapan teoritis masalah yang sudah diketahui oleh siswa, kemudian masalah tersebut di selesaikan dan dikembangkan oleh siswa berdasarkan pengalaman yang dimiliki siswa.

Pendapat lain yang menguatkan hasil penelitian ini, yaitu Bronack, dkk (2008) mengatakan strategi kontekstual dapat mengembangkan kemampuan dan keahlian siswa dalam pembelajaran matematika. Hasil penelitian Kocak, Radiye Bozan \& Ozlem Isik (2009) menujukkan bahwa siswa yang belajar dalam strategi pembelajaran kontekstual maka siswa tersebut dapat memahami materi dengan baik, mengemukakan ide-ide yang baru, belajar sesuai dengan tujuan pembelajaran yang akan dicapai, serta dapat menerapkan pengetahuan yang dimiliki bukan hanya menghafal rumus-rumus matematika yang ada.

Penerapan strategi pembelajaran kontekstual dapat meningkatkan koneksi matematika. Peningkatan tersebut terlihat dari meningkatnya indikator-indikator koneksi matematika dalam penelitian ini. Koneksi matematika diamati dari lima indikator, yaitu 1) mampu menyampaikan materi dengan baik kepada teman satu kelompok dalam diskusi, 2) mampu mengarahkan dan mau berbagi cara dengan menjelaskan tahapan-tahapan dalam penyelesaian soal dengan teman sebaya baik dalam kerja kelompok ataupun tidak, 3) berani maju ke dapan kelas untuk menyampaikan dan menjelaskan pendapat ataupun mengerjakan soal tanpa harus ditunjuk oleh guru, 4) mampu berkomunikasi secara efektif dengan orang lain dalam mencari tahu solusi dalam penyelesaian masalah (soal), dan 5) mampu menyelesaikan soal dengan konsep yang benar dan matang. Peningkatan masing-masing indikator diuraikan singkat di bawah.

Hasil analisis data dari 37 siswa kelas 8.3 semester genap 2019/2020 MTs Negeri 1 Pemalang, pada kodisi awal terlihat bahwa siswa yang mampu menyampaikan materi dengan baik kepada teman satu kelompok dalam diskusi sebanyak 4 siswa $(10,81 \%)$. Pada tindakan siklus Imenjadi 10 siswa $(27,03 \%)$ dan pada tindakan siklus IImeningkat menjadi 19 siswa $(51,35 \%)$.

Kondisi awal menunjukkan bahwa siswa yang mampu mengarahkan dan mau berbagi cara dengan menjelaskan tahapan-tahapan dalam penyelesaian soal dengan teman sebaya baik dalam kerja kelompok ataupun tidak sebanyak 3 siswa (8,11\%). Pada tindakan siklus Imenjadi 12 siswa (32,43\%) dan pada tindakan siklus II meningkat menjadi 20 siswa (54,05\%).

Pada kondisi awal terlihat bahwa siswa yang berani maju ke dapan kelas untuk menyampaikan dan menjelaskan pendapat ataupun mengerjakan soal tanpa harus ditunjuk oleh guru sebanyak 4 siswa (10,81\%). Pada tindakan siklus I menjadi 9 siswa $(24,32 \%)$ dan pada tindakan siklus II meningkat menjadi 14 siswa (37,84\%).

Kondisi awal menunjukkan bahwa siswa yang mampu berkomunikasi secara efektif dengan orang lain dalam mencari tahu solusi dalam penyelesaian masalah (soal) sebanyak 5 siswa $(13,51 \%)$. Pada tindakan siklus I menjadi 13 siswa $(35,13 \%)$ dan pada tindakan siklus II meningkat menjadi 21 siswa $(56,76 \%)$. 
Kondisi awal menunjukkan bahwa siswa yang mampu menyelesaiakan soal dengan konsep yang benar dan matang sebanyak 3 orang $(8,11 \%)$. Pada tindakan siklus I menjadi 12 siswa (32,43\%) dan pada tindakan siklus II meningkat menjadi 19 siswa $(51,35 \%)$. Data koneksi belajar matematika secara keseluruhan disajikan pada tabel 1 dan gambar 1 .

Tabel 1

Data koneksi matematika

\begin{tabular}{|c|c|c|c|c|}
\hline \multirow[t]{2}{*}{ No } & \multirow{2}{*}{$\begin{array}{c}\text { Indikator koneksi } \\
\text { matematika }\end{array}$} & \multirow{2}{*}{$\begin{array}{l}\text { Sebelum } \\
\text { tindakan }\end{array}$} & \multicolumn{2}{|c|}{ Sesudah tindakan } \\
\hline & & & Siklus I & Siklus II \\
\hline 1 & $\mathbf{A}$ & $\begin{array}{c}4 \text { siswa } \\
(10,81 \%)\end{array}$ & $\begin{array}{l}10 \text { siswa } \\
(27,03 \%)\end{array}$ & $\begin{array}{l}19 \text { siswa } \\
(51,35 \%)\end{array}$ \\
\hline 2 & B & $\begin{array}{l}3 \text { siswa } \\
(8,11 \%)\end{array}$ & $\begin{array}{l}12 \text { siswa } \\
(32,43 \%)\end{array}$ & $\begin{array}{l}20 \text { siswa } \\
(54,05 \%)\end{array}$ \\
\hline 3 & $\mathbf{C}$ & $\begin{array}{c}4 \text { siswa } \\
(10,81 \%)\end{array}$ & $\begin{array}{c}9 \text { siswa } \\
(24,32 \%)\end{array}$ & $\begin{array}{l}14 \text { siswa } \\
(37,84 \%)\end{array}$ \\
\hline 4 & D & $\begin{array}{c}5 \text { siswa } \\
(13,51 \%)\end{array}$ & $\begin{array}{l}13 \text { siswa } \\
(35,13 \%)\end{array}$ & $\begin{array}{l}21 \text { siswa } \\
(56,76 \%)\end{array}$ \\
\hline 5 & $\mathbf{E}$ & $\begin{array}{l}3 \text { siswa } \\
(8,11 \%)\end{array}$ & $\begin{array}{l}12 \text { siswa } \\
(32,43 \%)\end{array}$ & $\begin{array}{l}19 \text { siswa } \\
(51,35 \%)\end{array}$ \\
\hline
\end{tabular}

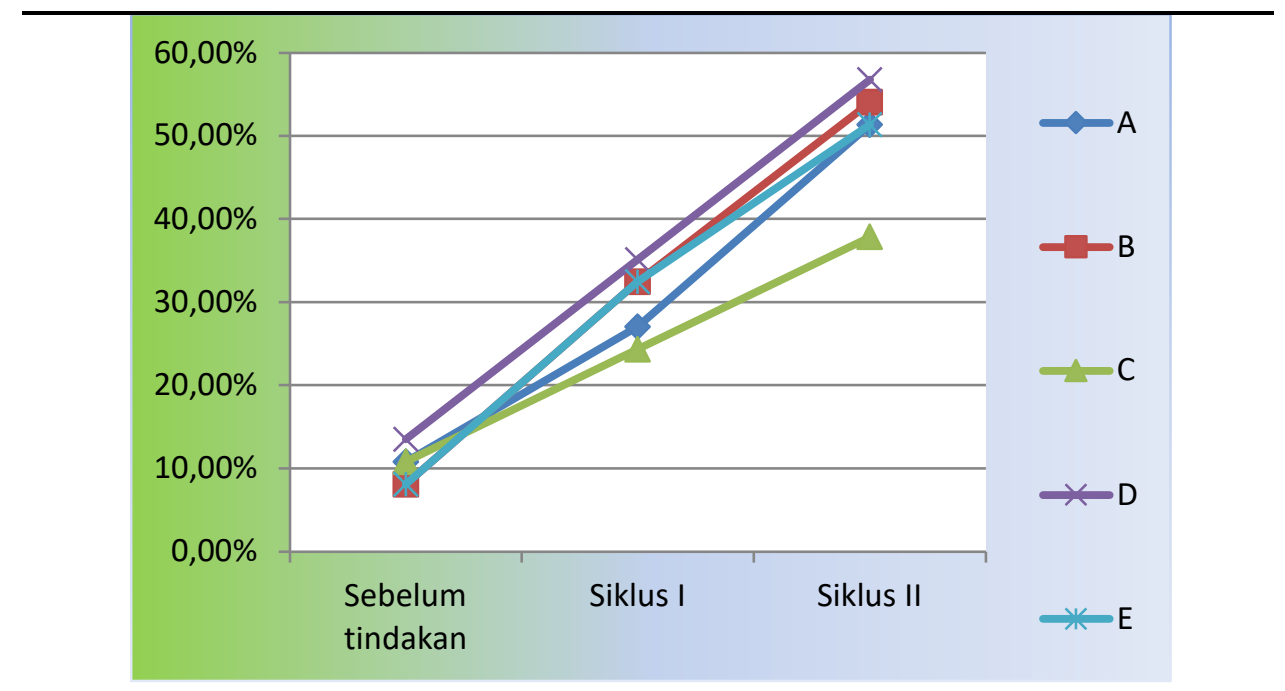

Gambar 1 Grafik peningkatan koneksi matematika

\section{Keterangan:}

A : Mampu menyampaikan materi dengan baik kepada teman satu kelompok dalam diskusi

B : Mampu mengarahkan dan mau berbagi cara dengan menjelaskan tahapan tahapan dalam penyelesaian soal dengan teman sebaya baik dalam kerja kelompok ataupun tidak 
C : Berani maju ke dapan kelas untuk menyampaikan dan menjelaskan pendapat ataupun mengerjakan soal tanpa harus ditunjuk oleh guru

D : Mampu berkomunikasi secara efektif dengan orang lain dalam mencari tahu solusi dalam penyelesaian masalah (soal)

E : Mampu menyelesaiakan soal dengan konsep yang benar dan matang

Koneksi matematika merupakan hal yang penting dalam pembelajaran. Koneksi matematika merupakan keterkaitan antar konsep atau ide matematika yang akan memfasilitasi kemampuan siswa untuk memformulasi dan memverifikasi konjektur secara induktif dan deduktif, selanjutnya konsep, ide, dan prosedur matematika yang baru dikembangkan dapat diterapkan untuk menyelesaikan masalah lain dalam matematika atau disiplin ilmu lainnya (Permana dan Utari Sumarmo, 2007: 117).

Hasil penelitian yang dilakukan olehSaldanha dan Patrick Thompson (2007) mendukung perlunya koneksi belajar dalam pembelajaran matematika. Hasil penelitian tersebut menujukkan bahwa koneksi matematika adalah keterkaitan konsep matematika yang terfokus pada perhatian siswa. Koneksi matematika dinilai dari aspek perkembangan siswa untuk menghubungkan konsep-konsep matematika. Penilaian diambil dari tes tertulis siswa yang mengacu pada instruksi soal yang telah di buat.

Berdasarkan uraian di atas, maka dapat disimpulkan bahwa koneksi matematika mengalami peningkatan. Hal ini berdampak pada meningkatnya hasil belajar siswa. Hasil belajar matematika dapat dilihat dari banyaknya siswa yang tuntas dengan nilai lebih dari sama dengan KKM. Peningkatan tersebut diuraikan singkat di bawah.

Pada kondisi awal terlihat bahwa siswa yang tuntas dengan nilai lebih dari sama dengan KKM yaitu 65 sebanyak 12 siswa atau 32,43\%. Pada tindakan siklus I menjadi 22 siswa $(59,46 \%)$ dan pada tindakan siklus II meningkat menjadi 29 siswa $(78,38 \%)$. Data hasil belajar matematika secara keseluruhan disajikan pada tebel 2 dan gambar 2.

Tabel2

Data hasil belajar matematika

\begin{tabular}{lllll}
\hline \multicolumn{1}{c}{ Indikator hasil belajar } & $\begin{array}{c}\text { Sebelum } \\
\text { tindakan }\end{array}$ & \multicolumn{2}{c}{ Sesudah tindakan } \\
\cline { 4 - 5 } & & & Sikkus I & Siktus H- \\
\hline & & & & \\
Nilai siswa lebih dari atau sama & 15 siswa & 22 siswa & 29 siswa \\
dengan KKM $(\geq \mathbf{6 5})$ & & $(32,43 \%)$ & $(59,46 \%)$ & $(78,38 \%)$ \\
\hline
\end{tabular}




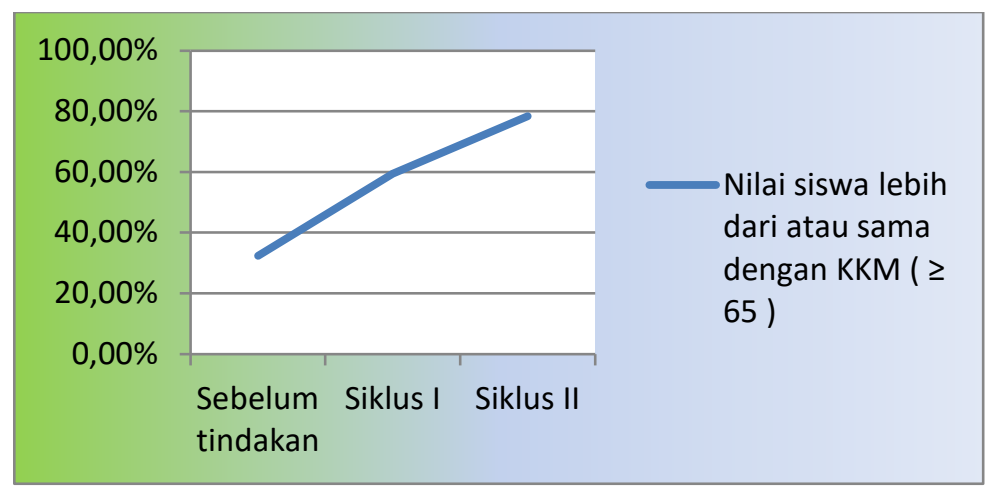

\section{Gambar 2 Grafik peningkatan hasil belajar matematika}

Hasil belajar adalah perubahan tingkah laku siswa secara nyata yang berupa kemampuan-kemampuan siswa yang diperoleh dari proses belajar. Adedoyin (2010) mengatakan, hasil belajar matematika dipengaruhi oleh gender dan cara mengajar guru dalam proses pembelajaran. Hasil penelitian yang dilakukan oleh Svanstrom (2008) juga mendukung pentingnya hasil belajar dalam pembelajaran matematika.

Hasil penelitian tersebut menunjukkan bahwa hasil belajar meliputi pemikiran yang sistestic, perkembangan kemampuan interpersonal dan intrapersonal yang ditekankan pada kemampuan yang ada dalam individu. Guru profesional harus berpengetahuan, berilmu, dan berkemampuan untuk meningkatkan kedisiplinan guna mengembangkan hasil belajar matematika. Pendapat lain yang menguatkan hasil penelitian ini, yaitu Tella (2007) mengatakan, hasil belajar matematika dipengaruhi oleh motivasi belajar siswa. Guru harus dapat menggunakan strategi pembelajaran yang sesuai materi agar siswa tertarik dan termotivasi dalam belajar sehingga hasil belajar matematika dapat maksimal.

\section{SIMPULAN}

Proses pembelajaran matematika dengan strategi kontekstual dilakukan dengan lima tahap. 1) orientasi siswa pada situasi masalah, 2) mengorganisasi siswa untuk belajar, 3) membimbing penyelidikan individual maupun kelompok, 4) mengembangkan dan menyajikan hasil karya, dan 5) menganalisis dan mengevaluasi proses pemecahan masalah.

Proses pembelajaran matematika dengan strategi kontekstual dapat meningkatkan koneksi belajar matematika. Peningkatan koneksi belajar matematika yaitu (1) siswa yang mampu menyampaikan materi dengan baik dari sebelum tindakan 10,81\%, siklus I 27,03\%, dan siklus II 51,35\%, (2) siswa yang mampu mengarahkan dan mau berbagi cara dari sebelum tindakan $8,11 \%$, siklus I $32,43 \%$, dan siklus II 54,05\%, (3) siswa yang berani maju ke dapan kelas untuk menyampaikan pendapat ataupun mengerjakan soal dari sebelum tindakan $10,81 \%$, siklus I 24,32\%, dan siklus II 37,84\%, (4) siswa yang mampu berkomunikasi secara efektif dengan orang lain dalam penyelesaian masalah dari sebelum tindakan $13,51 \%$, siklus I $35,13 \%$, 
dan siklus II 56,76\%, dan (5) siswa yang mampu menyelesaiakan soal dengan konsep yang benar dari sebelum tindakan $8,11 \%$, siklus I 32,43\%, dan siklus II 51,35\%.

Peningkatan koneksi belajar matematika berdampak pada peningkatan hasil belajar matematika. Peningkatan hasil belajar matematika yaitu siswa yang tuntas dari sebelum tindakan 32,43\%, siklus I 59,46\%, dan siklus II 78,38\%.

\section{DAFTAR PUSTAKA}

Adedoyin, Omobola. 2010."An Investigation of the Effect of Teachers'Classroom Questions on the Achievements of Students in Matehematics: Case Study of Botswana Community Junior Secondary School”. 2 (3): 313-329.

Bronack, Stephen, dkk. 2008. “ Presence Pedagogy: Teaching and Learning in a 3D Virtual Immersive World" 20 (1): 59-69.

Coker, Bunyamin. Hakan Catlioglu \& Osman Birgin. 2010."Conceptions of Students About Renewable Energy Sources: A Need to Teach Based on Contextual Approaches". 2: 1488-1492.

Debreli, Emre. 2012."Change in Beliefs of Pre-Service Teachers About Teaching and Learning English As A Foreign Language Throughout An Undergraduate Pre-Service Teacher Training Program”. 46: 367-373.

Deen, Ifraj Shamsid. 2006. "Contextual Teaching and Learning Practices in the Family and Consumer Sciences Curriculum”. 24 (1): 14-27.

Johnson, Elaine B. 2011. Contextual Teaching \& Learning. Bandung: Kaifa.

Khandaghi, Maghsood Amin dan Farasat, Maryam. 2011.’The Effect o Teacher's Teaching Style on Students' Adjusment". 15: 1391-1394

Kocak, Zeynep Fidan. Radiye Bozan \& Ozlem Isik. 2009. "The Importance of Group Work in Mathematics". 1:2363-2365.

Komalasari, Kokom. 2012.'The Effect of Contextual Learning in Civic Education on Students' Civic Skills. 4 (2): 179-190.

Perin, Dolores. 2011.’Facilitating Student Learning Through Contextualization” 29:1-62.

Permana, Yanto dan Utari Sumarmo. 2007. "Mengembangkan Kemampuan Penalaran dan Koneksi Matematika Siswa SMA Melalui Pembelajaran Berbasis Masalah". 1 (2): 116123.

Puteh, Marzita dan Ibrahim, Mahani. 2010.”The Usage of Self-Regulated Learning Strategies among Form Four Students in the Mathematical Problem-Solving Context: A Case Study". 8: 446-452.

Saldanha, Luis dan Patrick Thompson. 2007. "Exploring Connections between Sampling Distribution and Statistical Snference: an Analysis of Students' Engagement and 
Thinking in the Context of Instruction Involving Repeated Thinking in the Context of Instruction Involving Repeated Sampling” 2 (3): 270-297.

Suryawati, Evi. Kamisah Osman \& T. Subahan Mohd Meerah. 2010." The Effectiveness of RANGKA Contextual Teaching and Learning on Students' Problem Solving Skills and Sciectufic attitude". 9: 1717-1721.

Sutama, 2019. Metode Penelitian Pendidikan, Kuantitatif, kualitatif, PTK, Mix Method, R\&D. Sukoharjo: CV. Jasmine.

Svanstrom, Magdalena. 2008." Learning Outcomes for Sustainable Development in Higher Education" 9 (3): 339-351.

Tella, Adedeji. 2007.'The Impact of Motivation on Student's Academic Achievement and Learning Outcomes in Mathematics among Secondary School Students in Nigeria" 3 (2): 149-156.

Vikis, Elena A. 2008."Teaching and Learning in the Operating Room is a Two-Way Street: Resident Perceptions". 195: 594-598. 